\begin{tabular}{|c|c|c|}
\hline \multirow{2}{*}{$\begin{array}{l}\text { BENTHAM OPEN } \\
\text { CrossMark }\end{array}$} & $\begin{array}{c}\text { The Open Conference Proceedings } \\
\text { Journal }\end{array}$ & nos \\
\hline & $\begin{array}{l}\text { Content list available at: www.benthamopen.com/TOPROCJ/ } \\
\text { DOI: } 10.2174 / 2210289201607020012\end{array}$ & \\
\hline
\end{tabular}

\title{
Editorial
}

\section{Biodeterioration of Stone Monuments}

This single topic issue corresponds to selected oral presentations realised at the European Conference on Biodeterioration of Stone Monuments (ECBSM) that took place in Cergy-Pontoise on November 7, 2014.

The conference was organised with the support of the University of Cergy-Pontoise (http://www.u-cergy.fr/fr/ index.html), ERRMECe-EA1391 laboratory (http://errmece.u-cergy.fr/), LRMH-USR3224 laboratory (http://www.lrmh. fr/), and PATRIMA Foundation for Cultural Heritage Science (http://www.sciences-patrimoine.org/). Initiated by the universities of Cergy-Pontoise and Versailles-Saint Quentin en Yvelines, PATRIMA is a unique initiative. It is made up of prestigious cultural institutions including le "Musée du Louvre", la "Bibliothèque Nationale de France", le "Musée du Quai Branly", and le "Château de Versailles", many major research and restoration laboratories, scientists, historians, and conservationists. The purpose of the PATRIMA Foundation is to honour and promote cultural heritage through the development of international research and education programs.

The aim of ECBSM2014 was to provide an overview of the current understanding of stone colonisation, and biodeterioration by microorganisms and of corresponding treatments. The conference was an opportunity to bring together the academic, industrial and expert communities working on biodeterioration of historic monuments in stone.

Six articles make up this issue, covering the different topics of the conference corresponding to hot topics about biodeterioration of stone monuments.

The article presented by Piero Tiano, addresses the general problems associated with biodeterioration of monumental heritage, the possible human interventions to stop and prevent the alterations, defines biogeomorphogenesis and explains how physical/mechanical and chemical attacks can influence the localization and extension of biologically induced stone damage, presents an innovative Biodeterioration Ontological model and considers the possible development of a conceptual model of an interactive database MDDM (Management of Dynamic Durability Model).

The article presented by Ornella Salvadori and Annalaura Casanova Municchia, richly illustrated with beautiful photography, elucidates current knowledge on the significant role of fungi and lichens in the biodeterioration of stone monuments, and explains how lichens can have bioprotective or bioderiorative effects.

The article presented by Patrick Di Martino deals with Biofilms at the surface of stone monuments, defines the term Biofilm, explains its structure, composition and kinetics of development, presents the nature of the microorganisms colonizing the stone surface, and analyses the scientific publications about Biofilm and biodeterioration of stone monuments listed in the full-text scientific database ScienceDirect up to and including 2013.

The article presented by Francesca Cappitelli addresses Biocleaning technologies applied to cultural heritage surfaces and in particular technologies to remove sulphates, nitrates, and organic matter.

Stéphanie Eyssautier-Chuine and co-authors present an experimental study that evaluates two non-destructive technics, chlorophyll fluorescence and colorimetry, to assess the Chlorella vulgaris growth on stone surface treated by experimental treatments for preventing biofouling. Different patterns of algal development and different efficiencies of treatments are shown. A synergistic effect of particular cocktails of chemicals used at low concentrations is demonstrated.

Jorge R. Osman and co-authors present an experimental study that describes the use of molecular methods for the study of bacterial biodiversity present on the surface of sand and from pioneer desert sand plants Near Jizan, Saudi Arabia. The possible use of pyrosequencing of PCR-amplified V1-V3 regions of 16S rDNA genes from total extracted DNA for 
the study of the biodiversity of microorganisms colonizing the stone surface of cultural heritage monuments is under question.

Patrick Di Martino

Laboratoire ERRMECe-EA1391

Université de Cergy-Pontoise 95302 Cergy-Pontoise

France

Email: martino@u-cergy.fr

\section{(C) Patrick Di Martino; Licensee Bentham Open.}

This is an open access article licensed under the terms of the Creative Commons Attribution-Non-Commercial 4.0 International Public License (CC BY-NC 4.0)(https://creativecommons.org/licenses/by-nc/4.0/legalcode), which permits unrestricted, non-commercial use, distribution and reproduction in any medium, provided the work is properly cited. 